\title{
On the first South American species of the genus Anasaitis Bryant, 1950 (Aranei: Salticidae: Salticinae: Euophryini) from Cartagena, Colombia
}

\author{
О первом южкно-американском виде Anasaitis Bryant, 1950 \\ (Aranei: Salticidae: Salticinae: Euophryini) из Картахены, Колумбия
}

\author{
William Galvis ${ }^{*}$, Wilder Zapata-M², Jagoba Malumbres-Olarte ${ }^{3,4}$ \\ Вильям Гальвис ${ }^{*}$, Вильдер Сапата-М², Хагоба Малюмбрес-Омярте ${ }^{3,4}$
}

\footnotetext{
${ }^{1}$ Grupo de Investigación en Aracnología y Miriapodología (GAM-UN), Instituto de Ciencias Naturales, Universidad Nacional de Colombia, sede Bogotá, Colombia. E-mail: wlgalvisj@unal.edu.co

${ }^{2}$ Grupo de Investigación Hidrobiología \& Grupo de Biología Descriptiva y Aplicada, Departamento de Biología, Universidad de Cartagena, Colombia. E-mail: wilder214_@hotmail.com

${ }^{3} \mathrm{CE} 3 \mathrm{C}$ - Centre for Ecology, Evolution and Environmental Changes / Azorean Biodiversity Group and Universidade dos Açores, Angra do Heroísmo, Azores, Portugal. E-mail: jagoba.malumbres.olarte@gmail.com

${ }^{4}$ Finnish Museum of Natural History, University of Helsinki, Helsinki, Finland.

* Corresponding author.
}

KEY WORDS: Caribbean region, jumping spider, mangrove forest, taxonomy.

КЛЮЧЕВЫЕ СЛОВА: Карибский регион, мангровый лес, паук-скакунчик, таксономия.

ABSTRACT. A new species - Anasaitis champetera sp.n. (Salticidae: Salticinae: Euophryini), the first species of the genus Anasaitis Bryant, 1950 from South America - is described of the basis of both sexes collected from Caño del Oro, Tierra Bomba island, Cartagena (Bolívar), Colombia.

How to cite this article: Galvis W., Zapata-M W., Malumbres-Olarte J. 2020. On the first South American species of the genus Anasaitis Bryant, 1950 (Aranei: Salticidae: Salticinae: Euophryini) from Cartagena, Colombia // Arthropoda Selecta. Vol.29. No.4. P.481-485. doi: 10.15298/arthsel. 29.4.11

РЕЗЮМЕ. Новый вид - Anasaitis champetera sp.n. (Salticidae: Salticinae: Euophryini), первый вид рода Anasaitis Bryant, 1950 из Южной Америки описан по обоим полам, собранным в Каньо дель Оро, остров Тьерра Бомба, Картахена (Боливар), Колумбия.

\section{Introduction}

The New World genus Anasaitis Bryant, 1950 comprises a mostly-Antillean group of jumping spiders distributed from the United States and Cuba, throughout Jamaica, La Hispaniola, Puerto Rico, to Panama and the Central American Colombian region [WSC, 2020]. Of the 22 valid species, only Anasaitis canosa (Walckenaer, 1837) and A. canalis (Chamberlin, 1925) occur in the continental lands of North America (the southeastern USA and northeastern Mexico), and in Panama (Bocas del Toro, Canal Zone Biological Area) and Colombia (Chocó) respectively [Edwards, 1999; Richman et al., 2012; Galvis, Moreno, 2016].

In Colombia, the genus is currently represented by a single species $A$. canalis recorded by Galvis \& Moreno [2016] from both sexes from Sapzurro in the Chocó department, on the border with Panama. During the ecological and biodiversity study of spider communities of the Caribbean mangrove forests in the department of Bolívar of Colombia, we have collected males and females of an unknown Anasaitis species. This new species, which is described hereinafter, is the first true South American representative of the genus.

\section{Material and methods}

The material studied is deposited in the Arachnological Collection of Instituto de Ciencias Naturales of the Universidad Nacional de Colombia (ICN-Ar, Eduardo Flórez), Bogotá, Colombia. Digital photographs were taken with a Leica MC-170 HD digital camera attached to a Leica M205A stereomicroscope, and then combined by using the image stacking software Leica Application Suite version 4.6.0. The map was prepared in the Geographic Information System QGIS "A Coruña" (version 3.1, under license CC BY-SA 3.0). Raster files from NaturalEarth $($ and DivaGis $($ ) were used to perform the distributional map of the records

The format of description follows Galvis [2015]. Abbreviations used in the text and figures are as follows: a.s.l. above sea level; $\mathrm{CO}$ - copulatory opening; $\mathrm{d}$ - dorsal; $\mathrm{E}$ - embolus; FD - fertilization ducts; ID - insemination ducts; $\mathrm{m}$ - meters; me - medial; OC - ocular quadrangle; $\mathrm{p}$ - prolateral; $\mathrm{r}$ - retrolateral; RTA - retrolateral tibial apophysis; S - spermatheca; Spe - spermophore; TL proximal tegular lobe; v - ventral; vTB - ventral tibial bump. Measurements are in millimeters. 

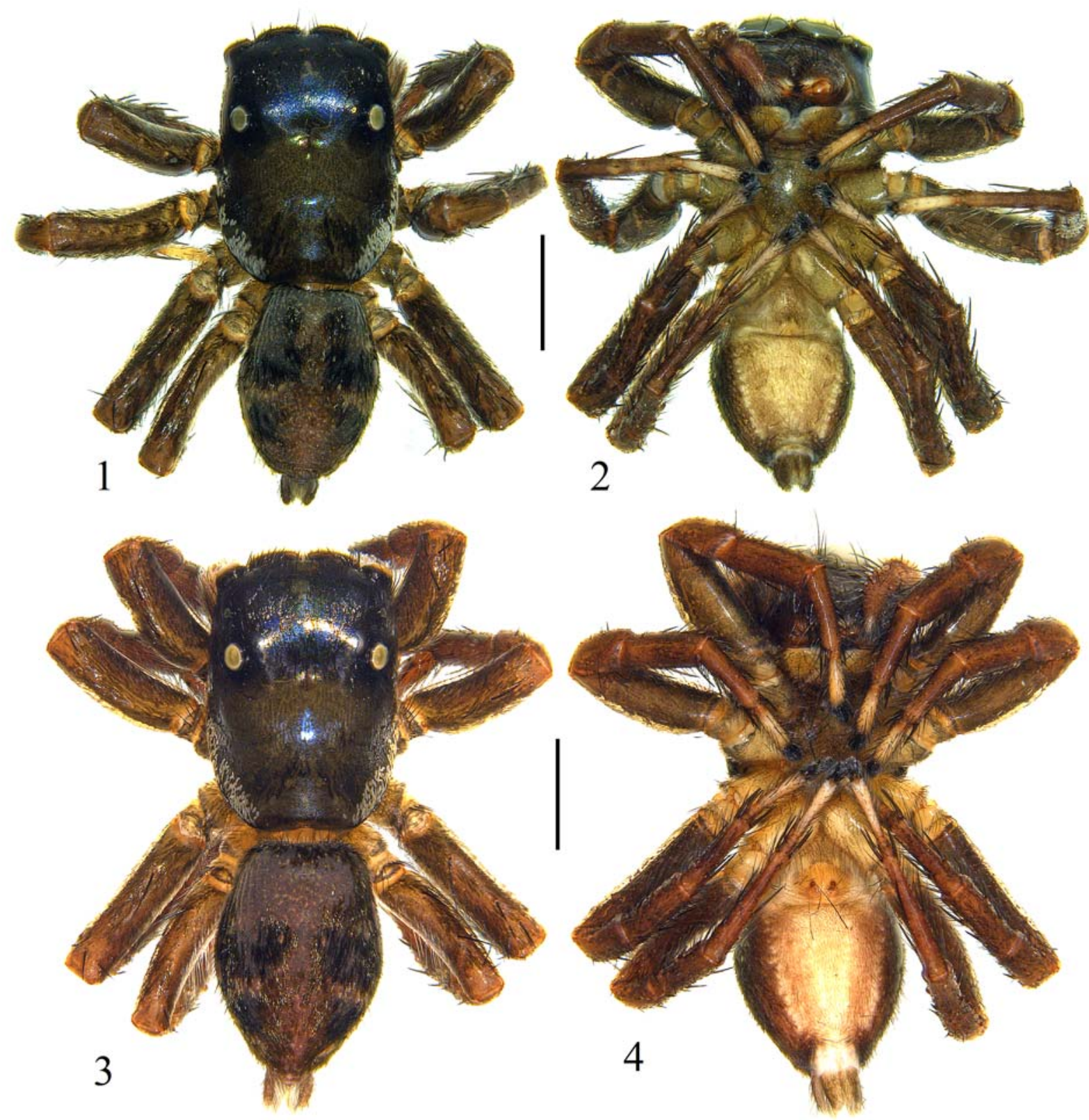

Figs 1-4. Anasaitis champetera sp.n. from Caño del Oro, Tierra Bomba island, Cartagena (Bolívar), Colombia. 1 - holotype male (ICN-Ar 10872), habitus, dorsal view. 2 - ditto, ventral view; 3 - paratype female (ICN-Ar 10873), habitus, dorsal view; 4 - ditto, ventral view. Scale bars: $1 \mathrm{~mm}$.

Рис. 1-4. Anasaitis champetera sp.n. из Каньо дель Оро, остров Тьерра Бомба, Картахена (Боливар), Колумбия. 1 - голотип самец (ICN-Ar 10872), габитус, вид сверху. 2 - то же, вид снизу; 3 - паратип самка (ICN-Ar 10873), габитус, вид сверху; 4 - то же, вид снизу. Масштаб: 1 мм.

\section{Taxonomy}

Family Salticidae Blackwall, 1841

Subfamily Salticinae Blackwall, 1841

Tribe Euophryini Simon, 1901

Anasaitis Bryant, 1950

Anasaitis Bryant, 1950: 168; the type species: Prostheclina morgani Peckham et Peckham, 1901.
Maeotella Bryant, 1950: 186; the type species: Prostheclina perplexa Peckham et Peckham, 1901. Synonymized by Zhang \& Maddison [2015].

DIAGNOSIS. Compared to Corythalia C.L. Koch, 1850 [Bryant, 1950; Edwards, 1999; Zhang, Maddison, 2012, 2013, 2015], Anasaitis includes small to medium-sized spiders, with high cephalothorax, stout-strong bodies and poorly fringed legs (legs highly fringed in Corythalia). The males usually have the short, not coiled embolus, the tegulum possessing a distinct proximal tegular lobe and the reduced distal haematodocha (long and coiled embolus with a dis- 

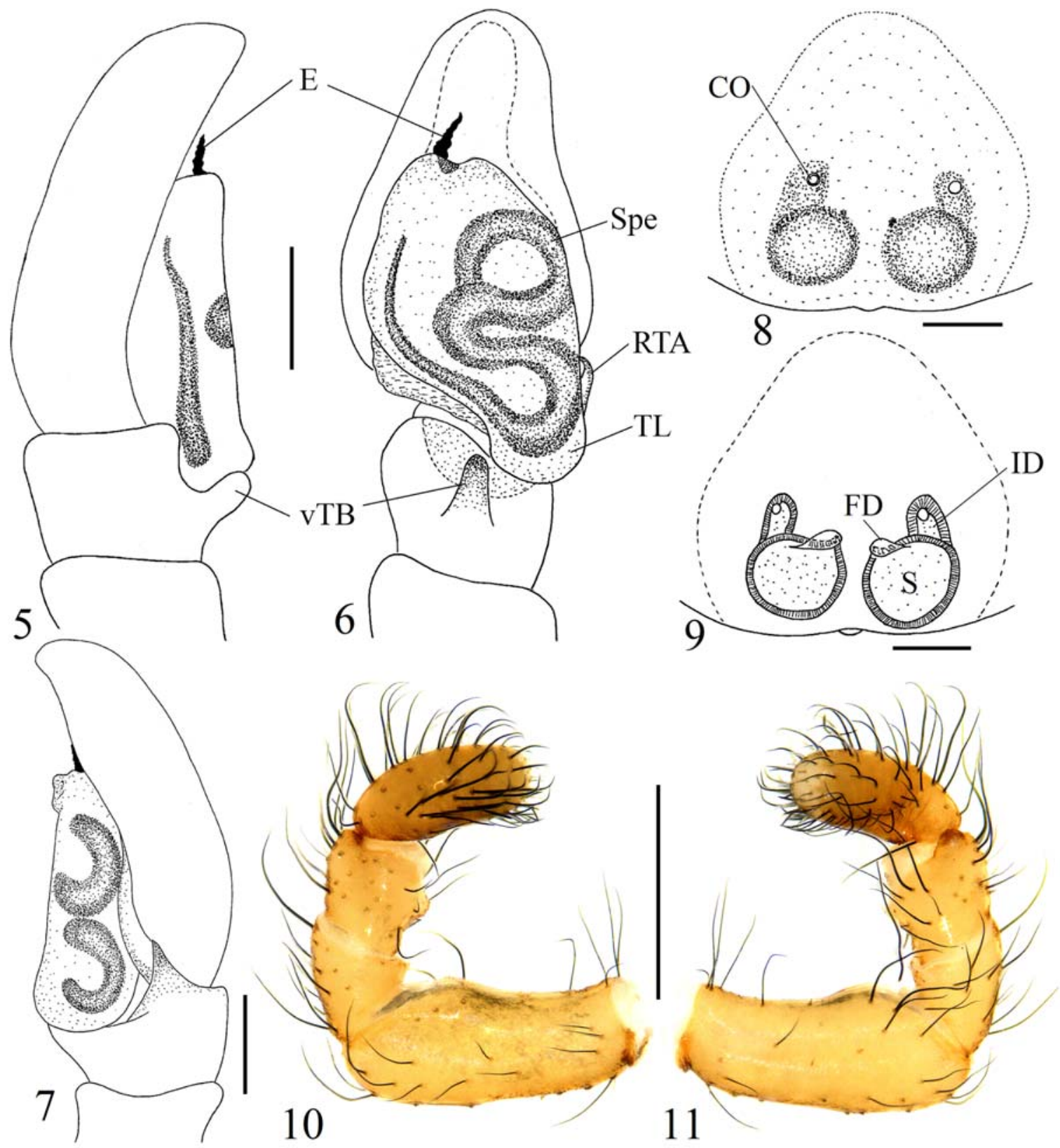

Figs 5-11. Anasaitis champetera sp.n. from Caño del Oro, Tierra Bomba island, Cartagena, (Bolívar) Colombia. 5 - left male palp, holotype (ICN-Ar 10872), prolateral view; 6 - ditto, ventral view; 7 - ditto, retrolateral view; 8 - epigyne, paratype female (ICN-Ar 10873), ventral view; 9 - vulva, dorsal view, cleared; 10 - left female palp, paratype (ICN-Ar 10874), retrolateral view; 11 - ditto, prolateral view. Scale bars: $0.15 \mathrm{~mm}(5-7), 0.1 \mathrm{~mm}(8,9), 0.5 \mathrm{~mm}(10,11)$.

Рис. 5-11. Anasaitis champetera sp.n. из Каньо дель Оро, остров Тьерра Бомба, Картахена (Боливар), Колумбия. 5 - левая пальпа голотипа-самца (ICN-Ar 10872), вид спереди-сбоку; 6 - то же, вид снизу; 7 - то же, вид сзади-сбоку; 8 - эпигина паратипа-самки (ICN-Ar 10873), вид снизу; 9 - вульва, вид сверху, очищена; 10 - левая пальпа паратипа-самки (ICN-Ar 10874), вид сзади-сбоку; 11 - то же, вид спереди-сбоку. Масштаб: 0,15 мм (5-7), 0,1 мм $(8,9), 0,5$ мм $(10,11)$.

tinct embolic disc, and the developed distal haematodocha in Corythalia). The females have the epigyne without a distinct "window" and the vulva with short insemination ducts (a distinct epigynal "window" and long insemination ducts in Corythalia).

COMMENTS. Hill [2009] described the courtship behaviour of A. canosa from the southern United States.

\section{Anasaitis champetera sp.n.}

Figs $1-12$.

TYPE. Holotype $0^{7}$ (ICN-Ar, 10872) from Sector Chavó $\left(10.35088^{\circ} \mathrm{N}, 75.54407^{\circ} \mathrm{W}\right)$, Caño del Oro, Tierra Bomba island, Cartagena, Bolívar, Colombia, 1 m a.s.1., 28-29.07.2018, W. Galvis and the MangrArach Team. Paratypes: $2 \sigma^{7} \sigma^{7}, 2$ ㅇ (ICN-Ar, 10873-10874), together with the holotype. 


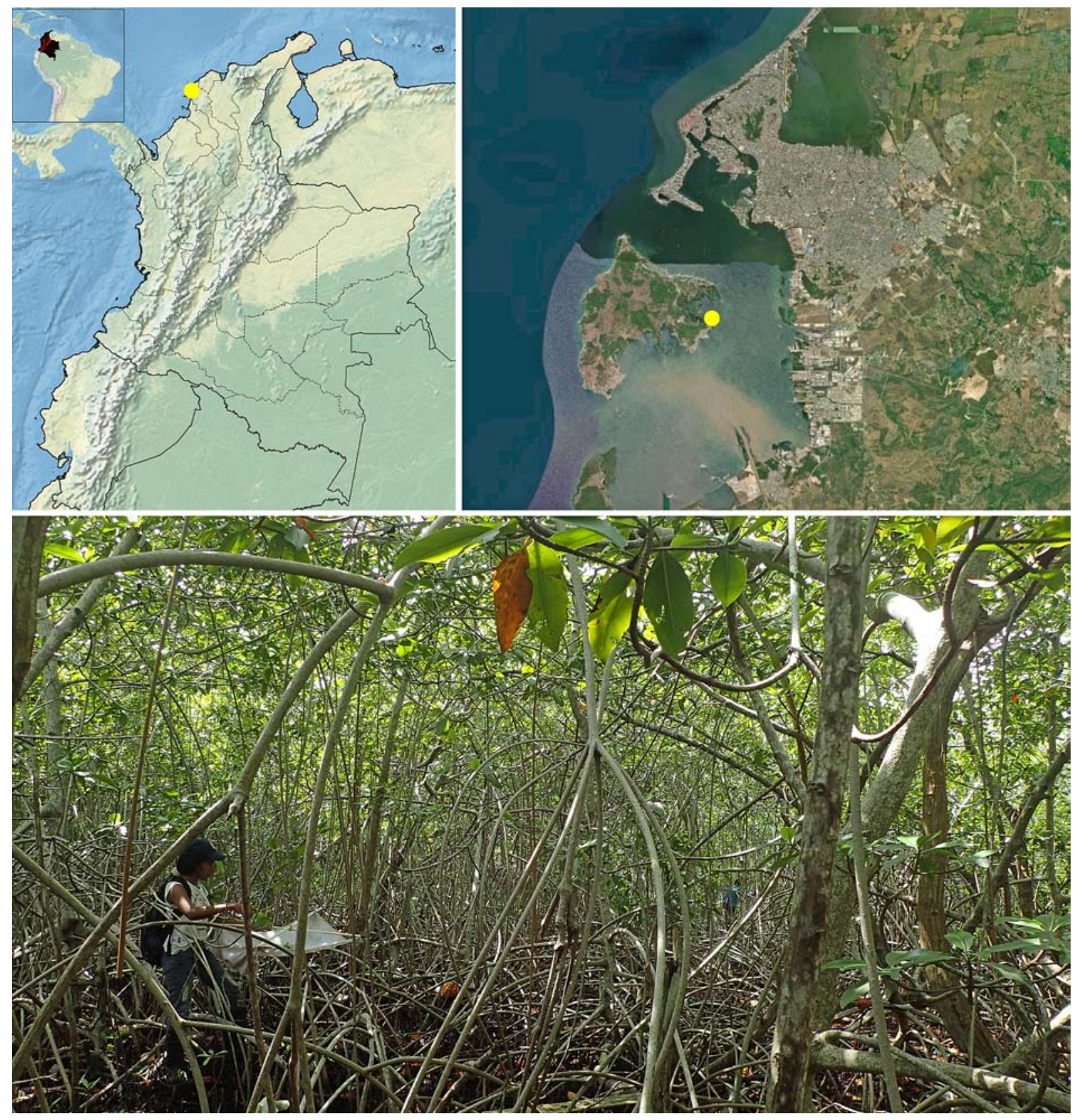

Fig. 12. Distribution map and a representative ecosystem of the type locality of Anasaitis champetera sp.n., from Sector Chavó, Caño del Oro, Tierra Bomba island, Cartagena (Bolívar), Colombia.

Рис. 12. Карта распространеия и обзазец экосистемы из типового локалитета Anasaitis champetera sp.n., из Каньо дель Оро, остров Тьерра Бомба, Картахена (Боливар), Колумбия.

ETYMOLOGY. The specific epithet is a noun in apposition taken to honor people who dance Champeta, one of the most important, beautiful and energetic Caribbean music genre from Colombia (of the African origin), and the main dance in the Cartagena area, where the species was found.

DIAGNOSIS. A. champetera sp.n. is distinguished from all its congeners, including the morphologically similar $A$. canosa (cf. figs 6-12 in Zhang \& Maddison [2015]), by the combined presence of the wide, long and pointed RTA, the well-developed ventral tibial bump (vTB) and tegular lobe (TL) and the straight and twisted embolus in the males (Figs 5-7). The females can be diagnosed by the medium-long insemination ducts and the absence of accessory glands (Figs 8-9).

DESCRIPTION. MaLe (holotype; Figs 1, 2, 5-7). Total length: 3.81. Variation $(n=3)$ : total length 3.81-4.74; carapace length 2.24-2.72. Carapace dark brown, with two lateral and posterior stripes of white scales, 2.24 long, 1.60 wide, 1.23 high (Fig. 1). OC dark brown, 0.86 long. Anterior eye row 1.52 wide, posterior eye row 1.40 wide. Sternum brown, 0.88 long, 0.69 wide. Labium brown, 0.33 long, 0.28 wide. Chelicerae dark brown, with one retromarginal tooth and one promarginal bicuspid tooth. Palp dark brown, with distal patella and tibia completely covered with white scales, 
with the wide, long and pointed RTA, the well-developed ventral tibial bump (vTB) and tegular lobe (TL) and the straight twisted embolus (Figs 5-7). Leg formula 2341; all legs dark brown, with yellowish tarsi. Leg macrosetae: femur, I d 1 di, p 1 di; II-III d 2 di, p 1 di, r 1 di; IV d 2 di; patella, I-II p 1 me; III-IV p 1 me, r 1 me; tibia, I v 2-2-2, p 1-1-1, r 1 di, II v 1-2-2, p 1-1-1, r 1 di; III-IV v 1-0-2, p 1-11, r 1-1-1, d 1 pr; metatarsus, I-II v 2-2, p 1-1, r 1-1; III-IV v 2-0-2, p 1-0-2, r 1-0-2, d 1 pr. Abdomen: dorsum dark brown, with three pairs of semi quadrangular/triangular black marks separated by a middle longitudinal gray stripe; venter light brown (Fig. 2). All body parts, especially dorsum, densely covered with black and greenish scales.

Female. Total length 4.87. Variation $(n=2)$ : total length 4.81-4.87; carapace length 2.49-2.54. Carapace dark brown, with two lateral and posterior stripes of white scales, 2.54 long, 1.96 wide, 1.25 high (Fig. 3). OC dark brown, 1.05 long. Anterior eye row 1.71 wide, posterior eye row 1.58 wide. Sternum brown, 1.05 long, 0.75 wide. Labium brown, 0.37 long, 0.32 wide. Chelicerae dark brown, with one retromarginal tooth, and one promarginal bicuspid tooth. Palp dark brown. Leg formula 3421; all legs dark brown, with yellowish tarsi. Leg macrosetae: femur, I d 1 di; II-III d 2 di, p 1 di; IV d 2 di; patellae, I-II p 1 me; III-IV p 1 me, r 1 me; tibiae, I v 1-2-2, p 1-0-1; II v 1-2-2, p 0-1-1; III 1-0-2, p 01-1, r 1-1-1, d 1 pr; IV v 1-0-2, p 0-1-1, r 1-1-1-1, d 1 pr; metatarsus, I-II v 2-2, p 1-1, r 1-1; III v 2-0-2, p 2 di, r 1-0-2; IV v 0-2-0-2, p 1-1-0-2, r 1-1-0-2. Abdomen: dorsum dark brown, with three pairs of semi quadrangular/triangular black marks separated by a middle longitudinal gray stripe; venter light brown (Fig. 4). All body parts, especially dorsum, densely covered with black and greenish scales. Epigyne (Figs 8,9) with medial and rounded copulatory openings, short insemination ducts without accessory glands, and rounded spermathecae.

COMMENTS. One paratype male possesses a teratological formation on its left palp (Figs 10-11).

HABITAT. The type series was hand-collected during daytime from the ground and leaf litter in well-preserved mangrove forest (Fig. 12), at one meter a.s.l. and some five meters off the coastal line. Some individuals were also seen on roots of the mangroves when the tide was high and sea water covered the mangrove's interior.

DISTRIBUTION. Only known from the type locality, the Tierra Bomba island, Cartagena (Bolívar) Colombia (Fig. 12).

Acknowledgements. We thanks the MangrArach Team: Alejandro Segovia, David Vergara, Laura Pérez, and Luis Pedroza (Universidad de Cartagena), Yanuba Valiente, and especially Alexandria Gabb and Richard Preziosi (Manchester Metropolitan University, UK) for inviting all team members to the project 'Diversity and ecology of the spider communities in the mangroves of Cartagena, Bolívar', that was possible thanks to the RCUK-CIAT Newton-Caldas Fund Sustainable Tropical Agricultural Systems Programme, supported by The Biotechnology and Biological Sciences Research Council (BBSRC), Economic and Social Research Council (ESRC), Natural Environment Research Council (NERC) and the International Center for Tropical Agriculture (CIAT). We are grateful to Jorge Tavera Vergara and his family for their hospitality and for helping us to successfully sample in Caño del Oro. We also thank staff of the Laboratorio de Equipos Ópticos Compartidos (LEOC), Departamento de Biología, Facultad de Ciencias, Universidad Nacional de Colombia for their help with photographing the examined material.

\section{Compliance with ethical standards}

Conflict of Interest: The authors declare that they have no conflict of interest.

Ethical approval: No ethical issues were raised during our research.

\section{References}

Bryant E.B. 1950. The salticid spiders of Jamaica // Bulletin of the Museum of Comparative Zoology. Vol.103. P.163-209.

Edwards G.B. 1999. Corythalia canosa (Araneae: Salticidae) reassigned to Anasaitis // Insecta Mundi. No.13. P.10.

Galvis W. 2015. Especies nuevas y reportes de arañas saltarinas de Colombia (Araneae: Salticidae: Euophryinae) // Revista Ibérica de Aracnología. Vol.26. P.35-41.

Galvis W., Moreno J.S. 2016. A new jumping spider species of the genus Maeota (Araneae: Salticidae: Euophryini), with new faunistic data of the tribe from Colombia // Caldasia. Vol.38. No.2. P.274-284.

Hill D.E. 2009. Euophryinae jumping spiders that extend their legs during courtship (Araneae: Salticidae: Euophryinae: Maratus, Saitis) // Peckhamia. Vol.74. No.1. P.1-27.

Richman D.B., Cutler B., Hill D.E. 2012. Salticidae of North America, including Mexico // Peckhamia. Vol.95. No.3. P.188.

WSC 2020. World Spider Catalog, version 21.0 // Bern: Natural History Museum; online at: http://wsc.nmbe.ch, accessed on 11 May 2020.

Zhang J.-X., Maddison W.P. 2012. New euophryine jumping spiders from the Dominican Republic and Puerto Rico (Araneae: Salticidae: Euophryinae) // Zootaxa. Vol.3476. P.1-54.

Zhang J.-X., Maddison W.P. 2013. Molecular phylogeny, divergence times and biogeography of spiders of the subfamily Euophryinae (Araneae: Salticidae) // Molecular Phylogenetics and Evolution. Vol.68. P. 81-92.

Zhang J.-X., Maddison W.P. 2015. Genera of euophryine jumping spiders (Araneae: Salticidae), with a combined molecular-morphological phylogeny // Zootaxa. Vol.3938. No.1. P.1-147.

Responsible editor D.V. Logunov 